UDC 667.64:678.026

S. Kovalevskyy, DSc, Prof., O. Kovalevska, PhD, Assoc. Prof.

Donbass State Engineering Academy, 72 Akademichna Str.,84313, Kramatorsk, Ukraine; e-mail: olenakovalevskaya@gmail.com

\title{
MAGNETIC RESONANCE PROCESSING OF MATERIALS
}

С.В. Ковалевський, О.С. Ковалевська. Магніторезонансна обробка матеріалів. Акустичні пристрої для визначення модуля пружності засновані на вимірі резонансної частоти коливань зразків в результаті впливу на зразок акустичних хвиль 3 послідовною зміною їх частот. Мета - розробка алгоритму підвищення твердості матеріалів за рахунок магніторезонансної обробки. В роботі показана можливість використання в якості рівномірного потоку для впливу на обсяг матеріалу магнітного поля, утвореного потужними постійними магнітами. Процес впливу на обсяг матеріалу експериментальних зразків полягав в тому, що вплив рівномірного магнітного потоку, що пронизує зразок, ініціюється в результаті резонансних коливань зразка, викликаних широкосмуговим впливом рівній амплітуди за допомогою генератора «білого шуму» і пьєзовипромінювача. Обробка зразків матеріалів, вміщених в рівномірний магнітне поле, резонансними полічастотними вібраціями з нанорозмірної амплітудою в межах 20-80 нм., дозволяє змінювати показники в'язкості матеріалу, модуля пружності матеріалу і твердості зразків матеріалу в бік поліпшення експлуатаційних властивостей виробів з цих матеріалів. Нанорозмірні амплітуди власних коливань об'єктів складної форми в енергетичних полях, до яких можна віднести рівномірні магнітні поля, можуть виконувати корекцію фізико-механічних властивостей матеріалів таких об'єктів з метою досягнення їх ідентичності або додання строго заданих властивостей.

Ключові слова: Магніторезонансна обробка, модуль пружності матеріалів, «білий шум», об'ємне зміцнення

S. Kovalevskyy, O. Kovalevska. Magnetic resonance processing of materials. Acoustic devices for determining the elasticity modulus based on the measurement of the samples frequency resonant oscillation due to the sample exposure to acoustic waves with consistently changed frequencies. Objective: Development of an algorithm for increasing the hardness of materials due to magnetic resonance imaging. Materials and methods: The paper shows the possibility of using as a uniform flux to influence the volume of the material of the magnetic field formed by powerful permanent magnets. The process of influencing the volume of material of the experimental samples was that the effect of a uniform magnetic flux permeating the sample is initiated in a result of resonant oscillations of the sample caused by broadband exposure of equal amplitude using a "white noise" generator and a piezoelectric emitter. Results: Treatment of samples of materials placed in a uniform magnetic field, resonant polyfrequency vibrations with nanoscale amplitude in the range of $20 . . .80$ nm, allows you to change the viscosity of the material, the modulus of elasticity of the material and the hardness of material samples to improve the performance of these materials . Conclusions: Nanoscale amplitudes of natural oscillations of objects of complex shape in energy fields, which include uniform magnetic fields, can correct the physical and mechanical properties of materials of such objects in order to achieve their identity or add strictly defined properties.

Keywords: Magnetic resonance processing, modulus of elasticity of materials, “white noise”, volume hardening

\section{Introduction}

When analyzing materials, their fundamental properties are the most informative. Such properties include elasticity [1]. Any material object can be considered to some extent as an elastic system that has well-defined types of natural oscillations with well-defined periods [2, 3]. Real deformable bodies have an infinite number of degrees of freedom corresponding to various states of deformation (bending, sliding, torsional, etc.). Therefore, there are also an infinite number of forms and frequencies of their own oscillations. Within a certain type of oscillations, in addition to the main, lower resonant frequency, you can always select an infinite number of higher harmonic oscillations. However, a limited number of oscillation forms with lower resonant frequencies are of practical importance.

An approximate solution of the problem of natural oscillations of round plates was given in [3]. Numerical methods using computers obtained dependences that relate the linear function of the natural oscillations of a round plate with the speed of propagation of longitudinal elastic waves [4].

The modulus of elasticity is a mathematical description of the ability of bodies or substances elastically to deform when a force is applied to them. The modulus of elasticity (Young's modulus) characterizes the tensile / compressive resistance of a material to elastic deformation, or the property of an object to deform along an axis under the influence of force along this axis and is defined as the ratio of stress to elongation [5]. Widely known acoustic devices [4, 6] for determining the modulus of elasticity, based on the measurement of the resonant oscillation frequency of the samples as a result of exposure to the sample of acoustic waves with a consistent change in their frequencies. To do this, the

DOI: 10.15276/opu.3.62.2020.04

(C) 2020 The Authors. This is an open access article under the CC BY license (http://creativecommons.org/licenses/by/4.0/). 
sample is installed between two piezoelectric elements (sensor and receiver) and gradually increase the frequency of the acoustic wave generator until the resonant frequency corresponding to the natural oscillations of the sample is reached $[4,6]$. On the basis of ideas about the physical nature of the influence of the composition of alloys and their structure on the modulus of elasticity the obtained results are analyzed. However, this device uses manual smooth adjustment of the oscillation frequency, approximate determination of the maximum on the screen of the oscilloscope, manual processing of the experimental results and a significant amount of time for the experiment as a whole.

\section{Analysis of recent research and publications}

There is also a device for measuring the elastic characteristics of materials by acoustic exposure by measuring the resonant frequencies of the samples, based on providing tuning to the resonant frequency at the maximum amplitude by changing only the phase of oscillations. This simplifies the method, but also does not preclude manual tuning to the resonant frequency and requires additional hardware, such as a feedback system and phase shifter.

Instruments and techniques developed to date, based on mechanical contact, allow measurements of the Young's modulus in a rather narrow range of absolute values [7]. This is due to both the design features of standard probes and the relative softness of the tip materials. At the same time, for objects where high rigidity is the main indicator of quality, measurement with existing instruments is not possible. The problem of determining the Young's modulus is especially acute in the study of multiphase structures, when there is a need to measure the elastic modulus of individual components, which differs from the value obtained by macroscopic measurements. In [7], a method for measuring the elastic modulus of Jung using a scanning probe microscope "Nanoscan" is proposed. The method allows measuring the Young's modulus on the scale of several hundred nanometers for a wide range of objects, including superhard materials. The method is based on measuring the dependence of the oscillation frequency of the probe in contact with the surface on the introduction of the needle tip into the surface under load.

All existing methods for determining the elastic properties of materials can be divided into static and dynamic [8]. Static methods are based on the experimental determination of the relationship between the load and the deformation of the sample, for example by stretching on a rupture machine. There are also methods for determining the elastic properties based on nanoindentation.

Dynamic methods, which include pulsed resonance and resonant methods with continuous excitation, allow the measurement of the velocity of elastic waves in the sample. This velocity is a function of elastic properties and density of the material and in the general case is function of the wave frequency and geometric parameters of the sample. Resonance pulse methods are based on the excitation of oscillations of the sample by means of short-term (pulse) influence, which has a broadband amplitude-frequency spectrum, and registration of the sample response. Calculation of the response spectrum of the sample allows identifying the resonant frequencies of its oscillations. These frequencies depend on the geometric dimensions and shape of the sample, the boundary conditions, as well as the density and elastic properties of the material. As a rule, boundary conditions close to the free ones are used, and in this connection, non-contact excitation and registration of oscillations are optimal, which allow to exclude the influence of the pathogen and the receiver on the oscillations of the sample. Resonant methods with continuous excitation are based on the excitation of oscillations of the sample by continuous exposure with a smoothly varying frequency and registration of the distribution of the amplitude of oscillations on the surface of the sample.

Many materials have high requirements for a set of performance properties - wear resistance, strength, heat resistance, viscosity, fracture $[9,10,11]$. One of the ways to increase the efficiency of the tool is to strengthen the bulk heat treatment [12]. However, since heat treatment for maximum hardness and wear resistance leads to a decrease in the viscosity and crack resistance of the cutting part of the tool, the problem of increasing the fracture toughness of the tool is relevant $[13,14]$.

Existing methods of changing the physical and mechanical properties of materials of the working surface of products can be divided into five main classes [10]:

1) application to the surface of a thin film layer; 
2) change in the chemical composition of the surface layer;

3) change the structure of the surface layer;

4) change in the energy reserve of the surface layer;

5) change the surface layer roughness.

As for the change of physical and mechanical properties throughout the volume of the product, this can be achieved by changing the structure of the material throughout the volume of the product by heat treatment (hardening), cryogenic treatment (hardening followed by cold treatment).

The hardening processes of claims 1 to 5 are aimed at the material of a thin surface layer of the working part of the tool and are based either on direct contact or use the effects of impulse of any nature, in which the effect acquires the properties of the skin effect [15]. Volumetric hardening during heat treatment has the effect that the uniform effect of heat flow on the entire volume of the tool material makes such volumetric processing and volumetric hardening possible. However, the uniformity of the heat flux requires time to equalize the temperature gradient in the volume of the material.

The aim of the study is to develop an algorithm for increasing the hardness of materials due to magnetic resonance imaging.

\section{Presentation of the main material}

The paper shows the possibility of using as a uniform flux to influence the volume of the material of the magnetic field formed by powerful permanent magnets. The process of influencing the volume of the material of the experimental samples was that the effect of a uniform magnetic flux permeating the sample is initiated in a result of resonant oscillations of the sample caused by broadband exposure of equal amplitude using a "white noise" generator and with a piezoelectric emitter.

The possibility of obtaining a positive effect of a change in the physical and mechanical properties of the material of the experimental samples is based on the following provisions.

It is know that the modulus of elasticity $E$ and the density of the material of the sample $\rho$ is associated with the resonant frequency f_0 of the sample by the following dependence [16]:

$$
f_{0}=K_{f} \sqrt{\frac{E}{\rho}},
$$

where $K_{f}$ - coefficient depending on the size of the sample.

In [17] it is noted that for cubic crystals, analogues of which are in the materials of hard alloys used in the production of cutting non-grinding plates are characterized by 3 types of elastic deformations and, accordingly, 3 independent elastic constants:

$$
C_{\alpha \beta}=\left.\frac{1}{V_{0}} \frac{\partial^{2} E}{\partial \eta_{\alpha} \eta_{\beta}}\right|_{\eta=0},
$$

where $\alpha, \beta$-indices showing the types of elastic deformations in the sample element; $V \_0$ the volume of the sample element; $\eta \_\alpha, \eta \_\beta$ deformations in different directions of the Cartesian coordinate system.

Here it is necessary to take into account the three-dimensional nature of vibrations (deformations) in the resonance of each element of the volume of the material. Therefore, the detection of the effect of volume effect on the physical and mechanical properties of the experimental sample can be made in a result of estimating the resonant frequency of the experimental sample and its change in the process of exposure to this sample. For this purpose, we used the dependence proposed in [18]:

$$
E=1.64 m L^{3} \frac{f^{2}}{d^{4}},
$$

where $m$ - mass of the sample, $L$ - the length of the sample, $d$ - the diameter of the sample.

Based on these initial conditions, the determination of the resonant frequency of the experimental sample placed in a uniform magnetic field and subjected to resonant vibrations by means of a piezoelectric emitter and a piezoelectric sensor is performed on the base of the frequency spectrum of the sample in the magnetic field (3): 


$$
\begin{gathered}
f_{0}=\frac{\sum_{i=1}^{n} f_{i} \cdot A_{1 i}\left(f_{i}\right)}{\sum_{i=1}^{n} A_{i}\left(f_{1 i}\right)}, \\
A_{1 i}=A_{i}-A_{0 i},
\end{gathered}
$$

where $A_{0 i}$ - the amplitude of the $i$-th degree of the frequency spectrum of the hardware part of the experimental stand in the absence of the excitation signal of the "white noise" generator; $A_{i}$ - amplitudes of the $i$-th degree of the frequency spectrum of the sample, installed in the zone of uniformly magnetic field of the experimental stand and excited by the signal of the generator "white noise" by means of a piezoelectric element that is part of the experimental stand; $A_{01 i}$ - natural amplitudes of the $i$-th degree of the frequency spectrum of the sample placed in a uniform magnetic field.

The choice of piezoelectric elements as an emitter and sensor is due to the ability to register electric potentials during vibration in a wide frequency range between $10 \mathrm{~Hz} . .20 \mathrm{kHz}$ [19, 20, 21].

\section{Results}

1. Testing of duralumin sample: before vibration treatment in a uniform magnetic field, the hardness of the sample with a diameter of $15 \mathrm{~mm}$ and a height of $8 \mathrm{~mm}$ is $60 \ldots 80 \mathrm{HB}$; after vibration treatment for 20 minutes the hardness of the sample was 208...212 HB. The increase in the sum of the individual sites of the amplitudes indicates that the sample becomes changing the viscosity of the material. This may indicate a change in energy consumption for excitation of the sample. The increase in the resonant frequency can be explain by the increase in the modulus of elasticity of the material. All this leads to an increase in the hardness of the material. The increase in the resonant frequency, which indicates a change in the physical and mechanical properties is $\Delta f_{0}=225 \mathrm{~Hz}$.

2. Copper sample test: before vibration treatment in a constant magnetic field, the hardness of the sample with a diameter of $20 \mathrm{~mm}$ and a height of $5 \mathrm{~mm}$ is $60 \ldots 100 \mathrm{HB}$; after vibration treatment for 20 minutes, the hardness of the sample was $220 \ldots .222 \mathrm{HB}$. A drop in the resonant frequency of the sample may indicate an increase in the density of the material, which leads to an increase in hardness. Simultaneous reduction of the integral characteristic of the frequency response of the natural oscillations of the sample also indicates an increase in energy consumption for resonant vibrations of the sample. The increase in the resonant frequency, which indicates a change in the physical and mechanical properties is $\Delta f_{0}=150 \mathrm{~Hz}$.

3. Testing of non-grinding cutting plates made of hard alloy T15K6. An increase in the resonant frequency of the sample $\left(\Delta f_{0}=120 \mathrm{~Hz}\right)$ may indicate an increase in the modulus of elasticity of the material while increasing its viscosity. This is typical for polycarbonates, polyamides, composite materials. Testing of plates during turning of a batch of parts $\varnothing 95.5 \mathrm{~mm}$ made of $40 \mathrm{X}$ steel with a feed of $0.5 \mathrm{~mm} / \mathrm{rpm}$ and a cutting speed of $150 \mathrm{~m} / \mathrm{min}$ dimensional wear of T15K6 plates decreased by $40 . .42 \%$. This is an argument in favor of vibration resonant processing of cutting inserts in a uniform magnetic field.

4. Testing of non-grinding cutting inserts made of hard alloy VK8. An increase in the resonant frequency of the sample $\left(\left(\Delta f_{0}=70 \mathrm{~Hz}\right)\right.$ may indicate an increase in the modulus of elasticity of the material while increasing its viscosity. Testing of gray cast iron with cutters made of hard alloy VK8 with a hardness of $200 \ldots 220 \mathrm{HB}$ when turning the sample with a cutting depth of $1.8 \mathrm{~mm}$ with a feed rate of $0.2 \mathrm{~mm} / \mathrm{rpm}$ and a cutting speed of $114 \mathrm{~m} / \mathrm{min}$ wear of plates with VK8 decreased by $32 \ldots .37 \%$. It is show that with increasing duration of such processing the increase in its efficiency decreases. In addition, the process of changing the properties of the materials continues after vibration resonance treatment in a uniform magnetic field for the next $3 \ldots 5$ days. The change of these properties is subject to exponential nature and for different materials has a different time constant. Then the indicators $\sum_{i=1}^{n} A_{i}\left(f_{1 i}\right)$ and $f_{0}$ are stabilized, which indicates the termination of the process of changing the properties of the material of the samples. 
The results of processing in the magnetic field of other groups of samples of non-grinding cutting plates are in Table 1.

Table 1

Hardness indices of non-grinding cutting inserts before and after magnetic resonance processing in a uniform constant magnetic field

\begin{tabular}{|c|c|c|c|c|c|}
\hline \multirow{2}{*}{ Marking } & \multirow{2}{*}{ Type of plate } & \multirow{2}{*}{ № plates } & \multicolumn{3}{|c|}{ Hardness during the experiment, HB } \\
\hline & & & Before & After & $\Delta \mathrm{HB}$ \\
\hline \multirow{6}{*}{$\begin{array}{l}\text { CNMA 120408E- } \\
\text { KD5,ACK15A }\end{array}$} & & 1 & 418 & 508 & 90 \\
\hline & & 2 & 427 & 508 & 81 \\
\hline & & 3 & 441 & 509 & 68 \\
\hline & & 4 & 443 & 512 & 69 \\
\hline & & 5 & 443 & 510 & 67 \\
\hline & & 6 & 445 & 508 & 63 \\
\hline \multirow{6}{*}{$\begin{array}{l}\text { WNMG 080408E-MC3 } \\
\text { AP301M }\end{array}$} & & 7 & 431 & 488 & 57 \\
\hline & & 8 & 422 & 485 & 63 \\
\hline & & 9 & 431 & 488 & 57 \\
\hline & & 10 & 420 & 494 & 74 \\
\hline & & 11 & 424 & 481 & 57 \\
\hline & & 12 & 421 & 477 & 56 \\
\hline \multirow{6}{*}{$\begin{array}{l}\text { WNMG 080412E-PD3 } \\
\text { AC250P }\end{array}$} & & 13 & 423 & 472 & 49 \\
\hline & & 14 & 432 & 469 & 37 \\
\hline & & 15 & 427 & 471 & 44 \\
\hline & & 16 & 428 & 480 & 52 \\
\hline & & 17 & 420 & 482 & 62 \\
\hline & & 18 & 413 & 476 & 63 \\
\hline \multirow{10}{*}{$\begin{array}{c}\text { SNGX 1206ANN-MM3 } \\
\text { AP351U }\end{array}$} & & 19 & 419 & 517 & 98 \\
\hline & & 20 & 415 & 522 & 107 \\
\hline & & 21 & 419 & 510 & 91 \\
\hline & & 22 & 420 & 515 & 95 \\
\hline & & 23 & 423 & 508 & 85 \\
\hline & & 24 & 427 & 510 & 83 \\
\hline & & 25 & 423 & 511 & 88 \\
\hline & & 26 & 427 & 512 & 85 \\
\hline & & 27 & 415 & 513 & 98 \\
\hline & & 28 & 405 & 512 & 107 \\
\hline
\end{tabular}

Such processing of non-grinding plates was accompanied by observations of the dynamics of change of indicators $\sum_{i=1}^{n} A_{i}\left(f_{1 i}\right)$ and $f_{0}$ presented in Table 2 . 
Table 2

Dynamics of change of indicators $\sum_{i=1}^{n} A_{i}\left(f_{1 i}\right)$ and $f_{0}$

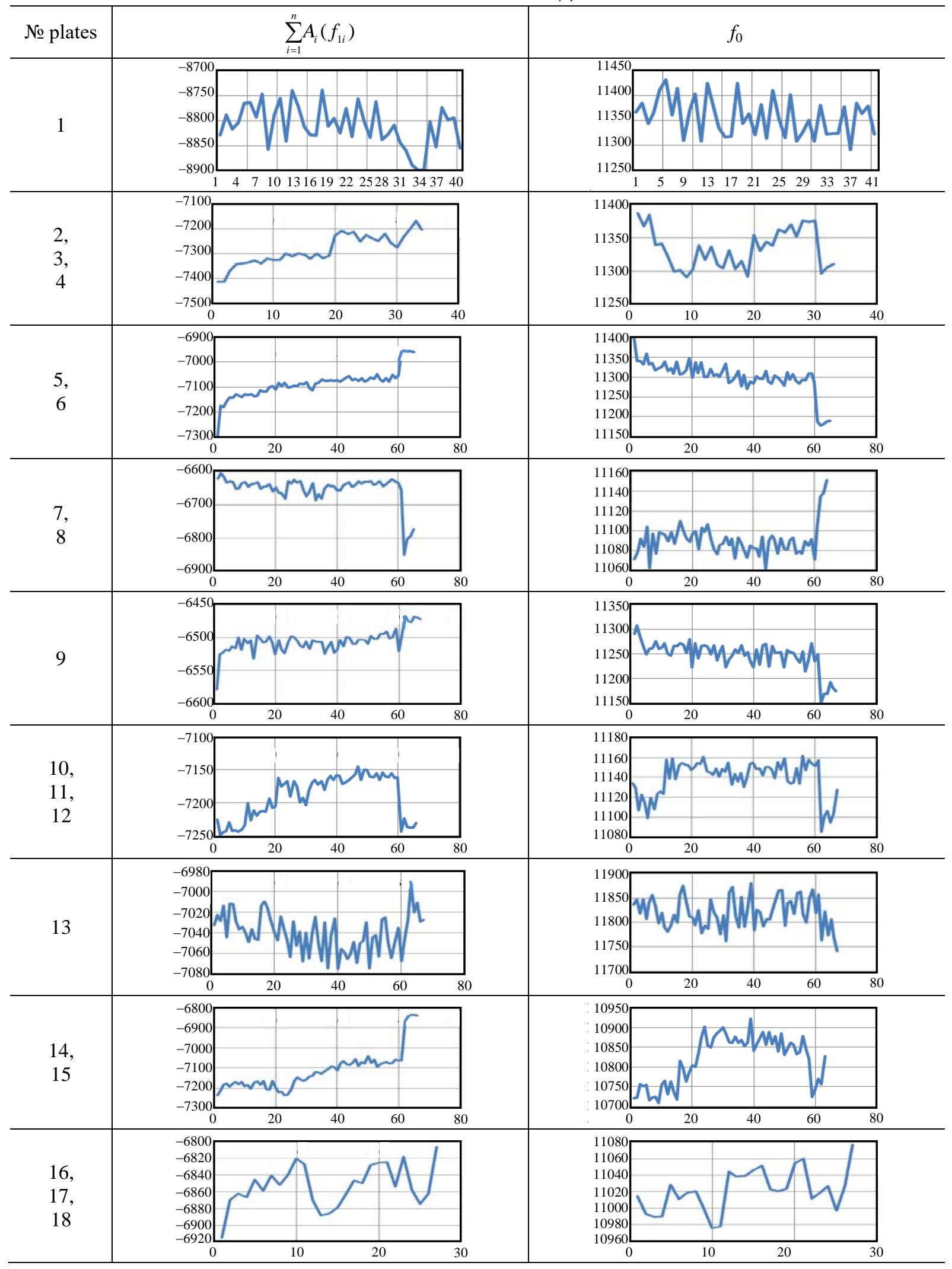


Approximation of change of indicators before and after processing of plates in a magnetic field is presented by polynomials of Table 3 .

Table 3

Approximation of change of indicators before and after processing of plates in a magnetic field

\begin{tabular}{|c|c|c|}
\hline $\begin{array}{c}\text { № } \\
\text { plates }\end{array}$ & Before processing & After processing \\
\hline 1 & $\begin{array}{c}y=-7 \mathrm{E}-06 x^{6}+0.0009 x^{5}-0.0449 x^{4}+1.0646 x^{3}- \\
-12.262 x^{2}+61.835 x-8887.2 \\
R^{2}=0.3295\end{array}$ & $\begin{array}{c}y=-4 \mathrm{E}-06 x^{6}+0.0005 x^{5}-0.0274 x^{4}+0.6685 x^{3}- \\
-7.9931 x^{2}+40.187 x+11320 \\
R^{2}=0.1538\end{array}$ \\
\hline $\begin{array}{l}2 \\
3 \\
4\end{array}$ & $\begin{array}{c}y=7 \mathrm{E}-06 x^{6}-0.0005 x^{5}+0.006 x^{4}+0.1811 x^{3}- \\
-5.2342 x^{2}+46.253 x-7465.4 \\
R^{2}=0.883\end{array}$ & $\begin{array}{c}y=1 \mathrm{E}-06 x^{6}-0.0002 x^{5}+0.013 x^{4}-0.3242 x^{3}+ \\
+4.5155 x^{2}-35.046 x+11427 \\
R^{2}=0.6571\end{array}$ \\
\hline $\begin{array}{l}5 \\
6\end{array}$ & $\begin{array}{c}y=-2 \mathrm{E}-07 x^{6}+4 \mathrm{E}-05 x^{5}-0.0037 x^{4}+0.1632 x^{3}- \\
-3.5733 x^{2}+38.345 x-7278.5 \\
R^{2}=0.9018\end{array}$ & $\begin{array}{c}y=7 \mathrm{E}-08 x^{6}-2 \mathrm{E}-05 x^{5}+0.0022 x^{4}-0.0988 x^{3}+ \\
+2.127 x^{2}-21.064 x+11399 \\
R^{2}=0.7988\end{array}$ \\
\hline $\begin{array}{l}7 \\
8\end{array}$ & $\begin{array}{c}y=7 \mathrm{E}-08 x^{6}-2 \mathrm{E}-05 x^{5}+0.0022 x^{4}-0.0988 x^{3}+ \\
+2.127 x^{2}-21.064 x+11399 \\
R^{2}=0.7988\end{array}$ & $\begin{array}{c}y=2 \mathrm{E}-07 x^{6}-3 \mathrm{E}-05 x^{5}+0.0023 x^{4}-0.0726 x^{3}+ \\
+0.9636 x^{2}-3.4156 x+11084 \\
R^{2}=0.6217\end{array}$ \\
\hline 9 & $\begin{array}{c}y=-6 \mathrm{E}-08 x^{6}+2 \mathrm{E}-05 x^{5}-0.0014 x^{4}+0.0636 x^{3}- \\
-1.4779 x^{2}+16.075 x-6569.7 \\
R^{2}=0.6803\end{array}$ & $\begin{array}{c}y=1 \mathrm{E}-07 x^{6}-3 \mathrm{E}-05 x^{5}+0.0027 x^{4}-0.1058 x^{3}+ \\
+2.0336 x^{2}-17.913 x+11317 \\
R^{2}=0.6644\end{array}$ \\
\hline $\begin{array}{l}10 \\
11 \\
12\end{array}$ & $\begin{array}{c}y=2 \mathrm{E}-07 x^{6}-4 \mathrm{E}-05 x^{5}+0.003 x^{4}-0.1171 x^{3}+ \\
+2.1844 x^{2}-14.125 x-7216.8 \\
R^{2}=0.8434\end{array}$ & $\begin{array}{c}y=2 \mathrm{E}-07 x^{6}-5 \mathrm{E}-05 x^{5}+0.0037 x^{4}-0.1414 x^{3}+ \\
+2.5073 x^{2}-16.142 x+11147 \\
R^{2}=0.5984\end{array}$ \\
\hline 13 & $\begin{array}{c}y=-6 \mathrm{E}-09 x^{6}+6 \mathrm{E}-07 x^{5}-1 \mathrm{E}-06 x^{4}-0.0013 x^{3}+ \\
0.0241 x^{2}-0.6317 x-7024.9 \\
R^{2}=0.342\end{array}$ & $\begin{array}{c}y=-5 \mathrm{E}-08 x^{6}+7 \mathrm{E}-06 x^{5}-0.0003 x^{4}+0.0039 x^{3}+ \\
+0.1219 x^{2}-3.9818 x+11845 \\
R^{2}=0.2437\end{array}$ \\
\hline $\begin{array}{l}14, \\
15\end{array}$ & $\begin{array}{c}y=-5 \mathrm{E}-08 x^{6}+3 \mathrm{E}-05 x^{5}-0.0035 x^{4}+0.1787 x^{3}- \\
-3.9025 x^{2}+33.588 x-7265.2 \\
R^{2}=0.9184\end{array}$ & $\begin{array}{c}y=-4 \mathrm{E}-08 x^{6}+3 \mathrm{E}-06 x^{5}+0.0004 x^{4}-0.0463 x^{3}+ \\
+1.6145 x^{2}-14.363 x+10761 \\
R^{2}=0.7982\end{array}$ \\
\hline $\begin{array}{l}16, \\
17 \\
18\end{array}$ & $\begin{array}{c}y=0.0001 x^{6}-0.0083 x^{5}+0.2479 x^{4}-3.3883 x^{3}+ \\
+20.096 x^{2}-35.008 x-6879.2 \\
R^{2}=0.6093\end{array}$ & $\begin{array}{c}y=5 \mathrm{E}-05 x^{6}-0.0038 x^{5}+0.1058 x^{4}-1.3926 x^{3}+ \\
+9.0349 x^{2}-25.365 x+11024 \\
R^{2}=0.4921\end{array}$ \\
\hline
\end{tabular}

The results of strengthening the non-grinding cutting plates are shown in Fig. 1 - 4 .

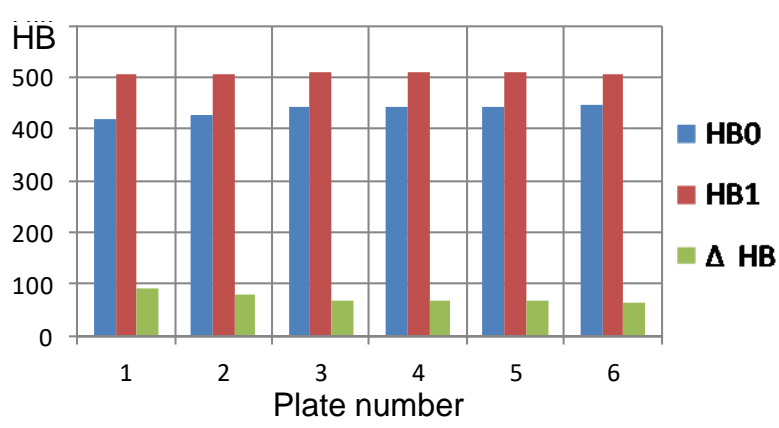

Fig. 1. Results of hardening of non-grinding cutting inserts type CNMA 120408E-KD5

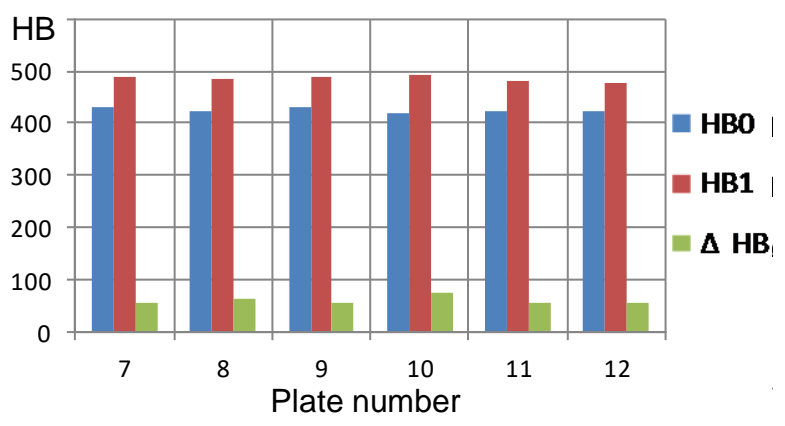

Fig. 2. Results of hardening of non-grinding cutting inserts type WNMG 080408E-MC3 AP301M 


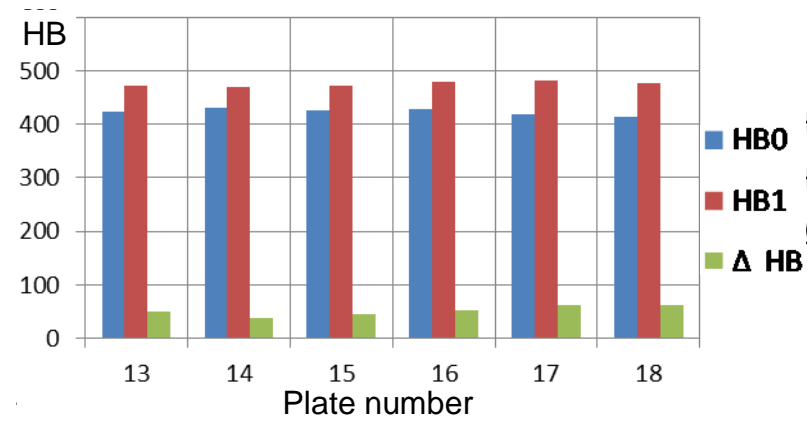

Fig. 3. Results of hardening of non-grinding cutting inserts type WNMG 080412E-PD3 AC250P

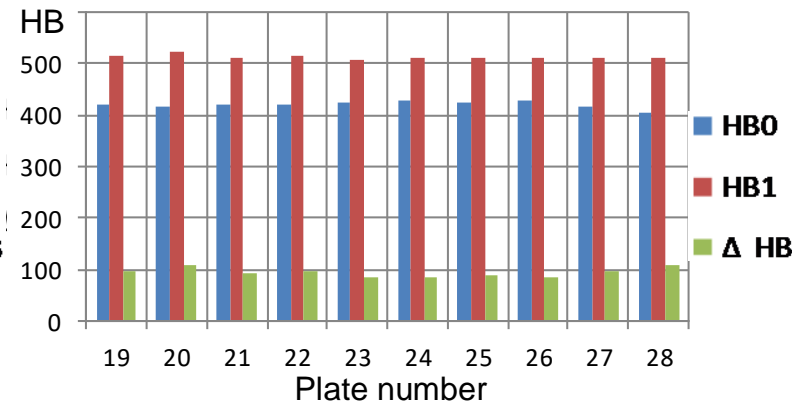

Fig. 4. Strengthening results of non-grinding SNGX 1206ANN-MM3 AP351U cutting inserts

Indicators of hardness and resonant frequencies of non-grinding cutting plates before and after magnetic resonance processing in a uniform constant magnetic field are presented in Table 4.

Table 4

The results of magnetic resonance processing of samples

\begin{tabular}{|c|c|c|c|c|c|c|c|}
\hline \multirow[b]{2}{*}{ Marking } & \multirow[b]{2}{*}{$\begin{array}{c}\text { № } \\
\text { plates }\end{array}$} & \multicolumn{2}{|c|}{ Before processing } & \multicolumn{2}{|c|}{ After processing } & \multicolumn{2}{|c|}{ Changes } \\
\hline & & $\begin{array}{c}\text { The hardness of } \\
\text { the plate, HB }\end{array}$ & \begin{tabular}{|c|} 
Resonance, \\
$\mathrm{Hz}$
\end{tabular} & $\begin{array}{c}\text { The hardness of } \\
\text { the plate, HB }\end{array}$ & $\begin{array}{c}\text { Resonance, } \\
f, \mathrm{~Hz} \\
\end{array}$ & $\Delta, \mathrm{HB}$ & $\Delta f, \mathrm{~Hz}$ \\
\hline \multirow{6}{*}{$\begin{array}{l}\text { CNMA 120408E- } \\
\text { KD5,ACK15A }\end{array}$} & 1 & 418 & 11365 & 508 & 11235 & 90 & 130 \\
\hline & 2 & 427 & 11403 & 508 & 11246 & 81 & 157 \\
\hline & 3 & 441 & 11403 & 509 & 11278 & 68 & 125 \\
\hline & 4 & 443 & 11403 & 512 & 11312 & 69 & 91 \\
\hline & 5 & 443 & 11400 & 510 & 11339 & 67 & 61 \\
\hline & 6 & 445 & 11400 & 508 & 11286 & 63 & 114 \\
\hline \multirow{6}{*}{$\begin{array}{c}\text { WNMG 080408E-MC3 } \\
\text { AP301M }\end{array}$} & 7 & 431 & 11092 & 488 & 11261 & 57 & -169 \\
\hline & 8 & 422 & 11092 & 485 & 11247 & 63 & -155 \\
\hline & 9 & 431 & 11291 & 488 & 11263 & 57 & 28 \\
\hline & 10 & 420 & 11134 & 494 & 11262 & 74 & -128 \\
\hline & 11 & 424 & 11134 & 481 & 11262 & 57 & -128 \\
\hline & 12 & 421 & 11134 & 477 & 11249 & 56 & -115 \\
\hline \multirow{6}{*}{$\begin{array}{c}\text { WNMG 080412E-PD3 } \\
\text { AC250P }\end{array}$} & 13 & 423 & 11835 & 472 & 11251 & 49 & 584 \\
\hline & 14 & 432 & 10776 & 469 & 11246 & 37 & -70 \\
\hline & 15 & 427 & 10776 & 471 & 11247 & 44 & -471 \\
\hline & 16 & 428 & 11014 & 480 & 11239 & 52 & -225 \\
\hline & 17 & 420 & 11014 & 482 & 11234 & 62 & -220 \\
\hline & 18 & 413 & 11014 & 476 & 11222 & 63 & -208 \\
\hline \multirow{10}{*}{$\begin{array}{c}\text { SNGX 1206ANN-MM3 } \\
\text { AP351U }\end{array}$} & 19 & 419 & 10785 & 517 & 11135 & 98 & -350 \\
\hline & 20 & 415 & 10957 & 522 & 11143 & 107 & -186 \\
\hline & 21 & 419 & 10655 & 510 & 11154 & 91 & -499 \\
\hline & 22 & 420 & 10694 & 515 & 11156 & 95 & -462 \\
\hline & 23 & 423 & 10849 & 508 & 11155 & 85 & -306 \\
\hline & 24 & 427 & 11249 & 510 & 11160 & 83 & 89 \\
\hline & 25 & 423 & 11249 & 511 & 11155 & 88 & 94 \\
\hline & 26 & 427 & 11249 & 512 & 11143 & 85 & 106 \\
\hline & 27 & 415 & 11070 & 513 & 11159 & 98 & -89 \\
\hline & 28 & 405 & 11070 & 512 & 11159 & 107 & -89 \\
\hline
\end{tabular}


The increase in hardness is inversely proportional to the decrease in the resonant frequency of the cutting plate. For different types of cutting inserts, the correspondence of hardness to resonant frequencies is different and obviously depends on the design features. Therefore, on average, the change in resonant frequency is determined by the formula: $\Delta \mathrm{HB}=-(0.65 \ldots 0.75) \Delta f_{0}$

For the plates of the most numerous group SNGX 1206ANN-MM3 AP351U) the result is described by formulas:

$\mathrm{HB}=-0.79 \cdot f_{0}+9317$.

$$
f_{0}=-1.27 \cdot \mathrm{HB}+11802
$$

The result can be described by the following dependence:

$$
f_{0}=-1.53 \cdot \mathrm{HB}+11981 \text {; }
$$

$\mathrm{HB}=-0.66 \cdot f_{0}+7856$

\section{Conclusions}

Processing of samples of materials placed in a uniform magnetic field by resonant polyfrequency vibrations with nanoscale amplitude in the range of $20 \ldots 80 \mathrm{~nm}$.

Nanoscale amplitudes of natural oscillations of objects of complex shape in energy fields, which include uniform magnetic fields, can correct the physical and mechanical properties of materials of such objects in order to achieve their identity or add strictly defined properties.

The study of this effect can be extended to a number of materials, their atomic-crystalline structures, ranges of magnetic fluxes, frequency ranges and estimates of the obtained physical and mechanical properties of the materials thus treated.

\section{Література}

1. Черняева Т.П., Грицина В.М., Михайлов Е.А., Остапов А.В. Корреляция между упругостью и другими свойствами циркония. Bопросы атомной науки и техники. 2009. Вып. 4. С. 206-217.

2. Приходько О. А., Манойлов В. В. Определение модуля нормальной упругости материала на основе преобразования Фурье акустических колебаний образца. Научное приборостроение. 2009. T. 19. № 3. С. 93-96.

3. Тимошенко С.П. Прочность и колебания элементов конструкций. Минск : Наука, 1975. 704 с.

4. Баранов В.М. Ультразвуковые измерения в атомной технихе. Минск : Атомиздат, 1975.

5. ГОСТ 25095-82. Сплавы твердые спеченные. Метод определения модуля упругости (модуля Юнга).

6. Клюев В.В. Приборы для неразрушающего контроля материалов изделий. Минск : Машиностроение, 1986. 488 с..

7. Усеинов А.С. Измерение модуля Юнга сверхтвердых материалов с помощью сканирующего зондового микроскопа НаноСкан. Приборы и техника эксперимента. 2003, №6, С. 1-5.

8. Минченя В. Т., Степаненко Д. А., Юрчик Е. Н. Расчет упругих постоянных материала по собственным частотам колебаний круглой пластины. Вестник Белорусского национального технического университета : научно-технический журнал. 2009. № 6. С. 37-42.

9. Ковалевський С.В., Глушич К.С. Удосконалення робочих поверхонь деталей машин методом епіламіровання. Молода наука - прогресивні технологічні прочеси, технологічне обладнання і оснащення. Збірник всеукраїнської науково-технічної конференції з міжнародною участю. 2018. С. 95-100.

10. Лолазде Т.Н. Прочность и износостойкость режущего инструмента. Москва : Машиностроение, 1982. $320 \mathrm{c}$.

11. Верещака А.С., Высоцкий В.В., Мокрицкий Б.Я. Технологические процессы повышения работоспособности металлорежущего инструмента. Комсомольск-на-Амуре : ФГБОУ ВПО «КнАГТУ», 2013. 208 с.

12. Скрынченко Ю.М., Позняк Л.А. Работоспособность и свойства инструментальных сталей. Київ : Наукова думка, 1979. 168 с.

13. Кремнев Л.С. Особенности разрушения инструментальных материалов. Металловедение и термическая обработка материалов. 1994. №4. С. 17-22.

14. Геллер Ю.А. Инструментальные стали. Москва : Металлургия, 1983. 527 с.

15. Самотугин С.С., Лещинский Л.К. Плазменное упрочнение инструментальных материалов. Донецк : Новый мир, 2002. 338 с.

16. Пименов Ю.В., Вольман В.И., Муравцов А.Д. Техническая электродинамика. Москва : Радио и связь, 2000. 536 с.

17. Ступин В.А. Определение упругих констант металлов ультразвуковым резонансным методом. Москва : ЦНИИатоминформ, 1985. 16 с. 
18. Golesorkhtabar R. ElaStic: A tool for calculating second-order elastic constants from first principles. Computer Physics Communications. 2013. Vol. 184. № 8. P. 1861-1873.

19. ГОСТ 25095-82. Сплавы твердые спеченные. Метод определения модуля продольной упругости. Москва: Изд-во стандартов, 1983. 7 с.

20. Kovalevskyy S.V., Kovalevska O.S. Acoustic Monitoring with Neural Network Diagnostics. American Journal of Neural Networks and Applications. 2015. Vol. 1. No. 2. P. 39-42.

21. Ковалевський С.В., Ковалевська О.С., Коржов С.О. Діагностика технологічних систем і виробів машинобудування (з використанням нейромережевого підходу). Краматорськ : ДДМА, 2016. 186 с.

\section{References}

1. Chernyaeva, T.P. (2009). Correlation between elasticity and other properties of zirconium. Scientific and technical comp. Nuclear Fuel Cycle, 4, 206-217.

2. Prikhodko, O.A., \& Manoilov, V.V. (2009). Determination of the modulus of normal elasticity of a material based on the Fourier transform of acoustic vibrations of the sample. Scientific instrumentation, 19(3), 93-96.

3. Timoshenko, S.P. (1975). Strength and vibrations of structural elements. Minsk: Nauka.

4. Baranov, V.M. (1975). Ultrasonic measurements in atomic engineering. Minsk: Atomizdat.

5. GOST 25095-82. (1982) Sintered hard alloys. Method for determining the elastic modulus (Young's modulus).

6. Klyuev, V.V. (1986). Devices for non-destructive testing of product materials. Minsk: Mechanical Engineering.

7. Useinov, A.S. (2003). Measurement of Young's modulus of superhard materials using a scanning probe microscope NanoScan. Devices and experimental technique, 6, 1-5.

8. Minchenya, V.T., Stepanenko, D.A., \& Yurchik, E.N. (2009). Calculation of elastic constants of a material by natural frequencies of vibrations of a round plate. Bulletin of the Belarusian National Technical University: scientific and technical journal, 6, 37-42.

9. Kovalevskiy, S.V., \& Glushich, K.S. (2018). Define the working surfaces of machine parts by the method of elimination. The science is young - progressive technological processes, technological possession and equipment. All-Ukrainian Science and Technology Conference with international participation. 95-100.

10. Lolazde, T.N. (1982). Durability and wear resistance of the cutting tool. Moscow: Mechanical Engineering.

11. Vereshchaka, A.S., Vysotskiy, V.V., \& Mokritskiy, B.Ya. (2013). Technological processes for increasing the efficiency of metal-cutting tools. Technological processes of increasing the working capacity of metal cutting tools. Komsomolsk-on-Amur: FGBOU VPO KnAGTU.

12. Skrynchenko, Yu.M., \& Poznyak, L.A. (1979). Serviceability and properties of tool steels. Kiev: Naukova Dumka.

13. Kremnev, L.S. (1994). Features of the destruction of tool materials. Metallurgy and heat treatment of materials, 4, 17-22.

14. Geller, Yu.A. (1983). Tool steels. Moscow: Metallurgy.

15. Samotugin, S.S., \& Leshchinsky, L.K. (2002). Plasma hardening of tool materials. Donetsk: Novy Mir.

16. Pimenov, Yu.V., Volman, V.I., \& Muravtsov, A.D. (2000). Technical electrodynamics. Moscow: Radio and communication.

17. Stupin, V.A. (1985). Determination of elastic constants of metals by ultrasonic resonance method. Moscow: TsNIIatominform.

18. Golesorkhtabar, R. (2013). ElaStic: A tool for calculating second-order elastic constants from first principles. Computer Physics Communications, 184 (8), 1861-1873.

19. GOST 25095-82. (1983). Sintered hard alloys. Method for determining the modulus of longitudinal elasticity. Moscow: Publishing house of standards.

20. Kovalevskyy, S.V., \& Kovalevska, O.S. (2015). Acoustic Monitoring with Neural Network Diagnostics. American Journal of Neural Networks and Applications, 1 (2), 39-42.

21. Kovalevsky, S.V., Kovalevska, O.S., \& Korzhov, E.O. (2016). Diagnostics of technological systems and virobuses of machinery (with the test of a neuromechanical approach). Kramatorsk: DDMA

Ковалевський Сергій Вадимович; Kovalevskyy Sergii, ORCID: https://orcid.org/0000-0002-4708-4091 Ковалевська Олена Сергіївна; Kovalevska Olena, ORCID: https://orcid.org/0000-0001-5884-0430 